\title{
CONTENTIOUS MOBILITIES AND Cheap(er) Labour: Temporary Foreign Workers in a New Brunswick Seafood Process- ING COMMUNITY
}

\author{
Christine KnOtT
}

\begin{abstract}
Canada's Temporary Foreign Worker Program (TFWP) is highly contentious. Particularly contentious are those parts of the program that have allowed for exploitative labour practices and the replacement of Canadian workers. Mobility for employment has been increasing, and researchers have focused on different types of mobile workers ranging from international (including the TFWP) to intra-provincial migrants, often in isolation from each other. Less research has focused on multiple mobilities within one industry to understand how and why labour force composition and employee mobility patterns change over time. Also under researched is why demand exists for TFWs in areas with high unemployment. This paper uses a case study of the seafood processing industry (both wild and farmed) in a rural region of New Brunswick to explore this industry's claims about labour shortages and serial reliance on differently mobile labour forces over time. It draws on findings from a review of relevant documents and ethnographic fieldwork including interviews. Using the historical changes in the (im)mobility patterns of processing workers in this region, this paper highlights how the increased use of the TFWP by seafood processing companies is tied to manufactured raced and gendered employer practices.
\end{abstract}

Keywords: Mobility, migration, citizenship, gender, fisheries, labour

Résumé. Le Programme des travailleurs étrangers temporaires (PTET) du Canada est très controversé. Les parties particulièrement controversées sont celles qui ont permis des pratiques d'exploitation des travailleurs et le remplacement des travailleurs canadiens. La mobilité pour l'emploi a augmenté et les chercheurs ont mis l'accent sur les différents types de travailleurs nomades allant de l'international (y compris le PTET) aux migrants interprovinciaux, souvent isolés les uns des autres. Un moins grand nombre de recherches portent sur les diverses mobilités au sein d'un même secteur afin de comprendre comment et pourquoi la composition de la population active et les modèles de mobilité des employés évoluent au fil du temps. La raison pour laquelle la demande existe 
pour des TET dans des régions où le chômage est élevé fait l'objet de trop peu de recherches. Cet article se sert d'une étude de cas du secteur de la transformation des fruits de mer (autant sauvages que d'élevage) dans une région rurale du Nouveau-Brunswick pour explorer les allégations de ce secteur quant aux pénuries de main-d'œuvre et une dépendance perpétuelle envers les diverses maind'œuvre nomades au fil du temps. Il s'appuie sur les conclusions d'un examen de documents pertinents et de travail ethnographique sur le terrain, y compris des entrevues. À l'aide des changements historiques dans les modèles d'(im)mobilité des travailleurs de la transformation de cette région, cet article met en lumière comment l'usage accru du PTET par les sociétés de transformation des fruits de mer est lié aux pratiques des employeurs axées sur l'ethnie et le genre.

Mots clés: Mobilité, migration, citoyenneté, genre, pêches, main-d'œuvre

\section{INTRODUCTION}

$\int \mathrm{h}$ he Temporary Foreign Worker Program (TFWP) in Canada has been a "hot" topic in recent years, receiving extensive media coverage between 2012 and 2014. The media coverage, among other things, highlighted specific vulnerabilities and abuses workers are susceptible to under the TFWP. These vulnerabilities and abuses include low wages, poor living and working conditions, reliance on employers for their ability to stay in Canada, and a lack of social and economic support systems (CBC News 2011; CBC News 2014a; CBC News 2014d; CBC 2014f). Also highlighted in the media has been the contentious replacement of Canadian workers by migrant workers, through the TFWP, as seen with cases involving the Royal Bank of Canada and McDonald's (see e.g. CBC News 2012, CBC News 2014b, CBC News 2014c).

The TFWP has also been widely contested among researchers. Research has linked the increasing use of the TFWP with decreased work quality and pay, and increased work flexibility, labour segmentation and precariousness for local workers (Preibisch 2007; Preibisch and Binford 2007). Thus the response from the public and researchers has been largely negative toward the TFWP. In response, the federal Conservative government overhauled the program in June 2014. Changes to the program included tighter restrictions on employers wanting access to the program, especially those located in areas with high unemployment rates (Canada 2014).

Seafood processing companies in Atlantic Canada, including many in high unemployment areas, became users of the TFWP between 2005 and 2014. As outlined in the Atlantic Provinces Economic Council Report Card, "[t]he number of TFWs employed in Atlantic fish plants grew 
from five in 2005 to 960 in 2012, with 90 percent of these working in New Brunswick and Prince Edward Island" (May 22, 2014, News Release). Not surprisingly, the Atlantic Canadian seafood processing industry vocally rallied against the regulation change, claiming they were dealing with extreme labour shortages in the industry (The Aurora on July 03, 2014; Morgan 2014). The lobbying efforts of the seafood processing industry over the next two years were met with success in the spring of 2016, when an exemption was made for the seafood processing industry in Atlantic Canada (CBC News 2016).

Labour supply issues are of significant economic and social concern, and the TFWP, despite its contentiousness, was developed to address labour shortages without influencing domestic employment rates (Gross 2014). Claims about labour shortages in Atlantic Canada's seafood processing industry are puzzling given the industry's long history of employing local and regionally migrant workers in a region and sector with high unemployment. This paper uses a case study of the seafood processing industry in a rural region of New Brunswick (NB) where both wild-caught and farmed fish are processed to explore the paradoxical relationship between claims of labour shortages and reliance on the TFWP in a high unemployment context. It showcases the intricacies of the industry's labour supply challenges in relation to how the industry's labour force has changed from local to now international via the TFWP.

The paper shows how the use of the TFWP in this context is a new labour strategy within an old system of raced and gendered practices used to recreate a cheap(er) and docile workforce. It provides insight into the Low-Skill Pilot Project stream of the TFWP, which is underrepresented in prior research. The paper argues that the New Brunswick seafood processing industry accesses cheap labour via racialized and classed processes that are mediated by the mobility as well as the immobility of workers. It also argues that employer recruitment and hiring practices are powerful agents in the manufacturing of qualitative labour shortages (Sharma 2006).

The remainder of the paper enters into the discussion of contentious labour force change and related shifting Employment-Related Geographical Mobility (E-RGM) in NB's seafood processing industry by first providing an overview of the TFWP in Canada, including the 2014 changes and discussing the inherent exploitation of workers who migrate temporarily (or in some cases permanently) to Canada. The paper then explores the historical connection between mobility, citizenship, race and gender in the context of seafood processing labour in NB, in order to understand how employer practices have been used over time to create docile and immobile workers. The third and final section of the paper 
links the theoretical approach with a historical overview of changes in the labour force in the NB industry to show how employer practices have played a role in manufacturing labour shortages used to justify reliance on the TFWP. This section also explores how new (and newly mobile), while at the same time captive labour forces, are indicative of global labour trends, and government immigration policies, such as the TFWP in Canada.

\section{The Temporary Foreign Worker Program In Canada}

Canada's TFWP is made up of multiple "streams", including the Seasonal Agricultural Workers Program (SAWP), the Live-in Caregivers Program, and the Pilot Project for Occupations Requiring Lower Levels of Foreign Training, or the Low-Skill Pilot Program (LSPP). The LSPP includes National Occupation Categories (NOC) C and D, such as seafood processing. It is this LSPP stream of the TFWP that is the focus of this paper.

The federal government introduced the Non-Immigrant Employment Authorization Program (NIEAP) in 1973 (Marsden 2011). This program focused mainly on higher skilled workers, but set the stage for the LSPP introduced in 2002. The LSPP tied workers to one employer for a temporary amount of time, divided work into low skill and high skill categories (by creating a special program for low-skilled work) and, similar to other temporary migrant worker programs, did not afford these workers the same rights as regular immigrants, restricting their access to social and economic benefits, permanent immigration, and political representation (Marsden 2011: 45). From 2002 to 2005, the program saw small but continual increases in the numbers of workers coming into Canada (Canada 2014). In 2006 the program was expanded under the Conservative government, and the numbers went from 3,769 workers in 2006, to a high of 25,660 workers in 2008 (Canada 2014). Some have claimed numbers were almost as high as 70,000 (Cragg 2011). This same year (2008), for the first time in Canadian history, the number of workers entering Canada through the TFWP exceeded that of those entering to become permanent residents (Cragg 2011).

The increase in the use of the TFWP in Canada eventually resulted in increased scrutiny from media and researchers. In June of 2014, the TFWP was significantly reworked (see Canada 2014 for a detailed overview of the changes) resulting in a limit on how many workers employers could bring in to work in low wage positions and the period of time they could stay. New regulations allow only $10 \%$ of a workforce to be 
composed of TFWP workers by 2016, and any workplace with more than 30 percent comprised of migrant workers was not allowed to bring in more workers. After intense lobbying efforts, the new Liberal government exempted the Atlantic Canada seafood processing industry from the cap for 2016. Employers are permitted an unlimited number of workers for a maximum of 180 days (CBC News 2016).

The TFWP is an economic migrant system that is based on creating two types of workers, with different rights, protection and citizenship. The program positions workers with different relationships to employers and communities side by side in the same industry and often the same plants. Workers coming through this program operate on a different playing field from workers who have Canadian citizenship, or have open work permits because of their inability to change employers and other sources of vulnerability (Gardiner Barber 2013; Mertins-Kirkwood 2014).

The TFWP's inherent inequality is not new. It draws upon and reentrenches long standing histories in Canada of racism, imperialism, and patriarchy that have long sorted labour migrants into different economic, social, and legal playing fields (Sharma 2006: 75). Research on the history of immigration policies in Canada has documented the role of these policies in (re)creating segmented citizenship rights, opportunities and experiences (Sharma 2006). These segmented citizenship rights are fractured along intersections of race, gender, and class (as well as other structured inequalities including, for example, age/disability) and are tied to mobility and immobility as these relate to work and citizenship.

Other Canadian studies show governments, employers, and migrant placement agencies hold gendered and racialized preferences for migrant workers who may face more severe limitations and options than Canadian workers if their work contract is unfavourable or, worse, unsafe (Preibisch and Binford 2007). The ability of employers to specify not only the sex but also the nationality of their employees contravenes both national and provincial human rights legislation (Preibisch 2010). Furthermore, temporary migrants entering Canada through the LSPP are more vulnerable than resident workers to occupational health and safety risks (see Fudge 2011; Fudge and MacPhail 2011; Preibisch 2011).

Preibisch $(2007,2010,2011)$ argues that immigration policies in high-income countries have become important arenas for labour regulation that aid in maintaining Canada's global competitiveness within horticulture by helping to create a flexible workforce via gender, racial/ethnic, and citizenship inequalities (Preibisch 2007; Preibisch and Binford 2007). From this perspective, the ability of employers to hand pick their employees involves more than just accruing a cheap labour 
supply segmented by citizenship, race, gender and class; it also entails a process of labour reorganization (Preibisch 2007, Sharma 2006) that increases the precariousness of occupations that employ migrant workers (Fudge 2011) helping to manufacture the Canadian labour shortages that are used to justify increasing reliance on the TFWP.

Preibisch and others draw on citizenship theories (MacDonald 2006; Basok 2003; Benach et al. 2010; Brysk and Shafir 2004; Fudge 2011; Gravel et al. 2009; Hennebry 2010; Marsden 2011; Preibisch 2007), as well as mobility theories (Cresswell 2010; Hannam et al. 2006; Sheller and Urry 2006; Büscher and Urry 2009), as a way to understand the risks, limited protections, and ultimately exploitation these workers experience. Historically informed studies, like the work of Preibisch (2007, 2011) and Sharma (2006), provide crucial insights into the processes behind the paradox between high rural unemployment rates in some regions, growing reliance on the TFWP and changing working conditions despite constraints in TFWPs that are designed to limit their impact on Canadian labour markets. One of the strengths of these studies is their attention to diverse and changing labour forces engaged in intra-provincial, interprovincial and international patterns, or spectrum of E-RGM. Attending to this changing spectrum of geographical mobility to, from and within work including drivers for these changes and their consequences for employers, workers and regional and sectoral labour markets, helps us understand the paradox at the center of this paper (Haan, Walsh and Neis, 2014; Roseman, Gardiner Barber and Neis 2015). Crucial to this, however, is the relationship between work, mobility and power. Feminist mobility theorist Silvey (2005: 138) argues mobility is socially embedded in that it reflects, as well as reinforces, social divisions such as those by gender, race, and class. Mobility "is ascribed with meanings in and through existing hierarchies and spatialities of power" and intersections of difference both define and redefine power relations as well as "community" politics (Silvey 2005: 144). Thus including a feminist lens to mobility research aids in understanding how migrant workers are tightly interwoven within the power relations that intersect mobile workers across time, space and place. Also important are insights from Grosfoguel et al. (2014) who argue for the importance of colonial legacies and racism in understanding how complex power constellations sort migrants above or below a "zone of being", in other words, sorting those who are seen and treated as human beings separately from those who are not. This human/non-human line is crucial to understanding the significance of allowing an immigration policy such as Canada's TFWP to exist. This policy creates a quasi "indentured" workforce with restricted citizen rights and gives employers control over an individual's 
ability to remain in Canada. It also creates a highly competitive, mobile, just-in-time workforce, access to which affects all workers in the industry including their work-life rhythms and their communities, as the case study of seafood processing in a NB region outlined below exemplifies.

\section{Gendered, Classed \& Racialized Seafood Processing Labour}

There is very little research on the use of the TFWP in seafood processing in Canada. One reason for this is the overall neglect of seafood processing workers who constitute an almost invisible part of Canadian fisheries (Guppy 1987; Lee 1983; Stainsby 1994). Some research on the history of seafood processing in $\mathrm{BC}$ demonstrates the importance of changing intersections of race, class, gender and mobility within this labour force over time. Muszynski (1996) argues that immigrant and aboriginal women in salmon canneries constituted a reserve army of labour, who, at the turn of the 20th century in coastal British Columbia were hired and fired at will. Stainsby's (1994) work shows this was still the case in the early 1990's in BC seafood processing plants. Thus in BC, gender, race, class, and E-RGM have been important factors in the ongoing construction of seasonally available, segmented groups of workers willing to work for cheap wages into the $21^{\text {st }}$ century. As pointed out by Muszynski (1996: 135), "[c]anners kept jobs segregated by race and gender, so that encroachments made by specific groups of labourers were perceived in racial terms rather than as a method allowing employers to keep labour costs minimal". If and when these workers quit, they were quickly and easily replaced in the past by locally constructed supplies of surplus workers and more recently, through access to the TFWP. The history of NB seafood processing work shares important similarities to seafood processing in $\mathrm{BC}$.

\section{Labour Shortages in the Atlantic Seafood Processing Industry}

This section will present findings from a case study of reliance on the TFWP in the aquaculture and capture seafood processing industry in one region of NB. The seafood processing industry is significant to rural coastal communities in NB. It is inherently tied to the fishing industry. The wild fishery in NB is a significant employer in all parts of NB, even in those areas that do not have large fishing sectors. Approximately 7,000 people were employed in 2010, many of which were 5th or 6th generation fish harvesters (New Brunswick 2007, Wiber et al. 2012). A 2008 report (GardnerPinfold 2010 iii), estimated that about "one in fourteen New Brunswick jobs is directly or indirectly dependent on the oceans". 
Thus the fishery, including seafood processing, is an important economic driver in the province.

As part of their lobbying efforts against the 2014 changes to the TFWP for their sector, seafood processing companies in rural Atlantic Canada argued reliance on the program was justified by quantitative local labour shortages resulting from out-migration and temporary mobility for work to Western Canada, aging populations, and the high use of Employment Insurance (EI) (e.g. CBC News 2014e). In contrast, some previous and current fish plant workers, reacting in their own defense in the comment sections of related news stories, clearly identified qualitative aspects of labour shortages as the problem, including poor wages and working conditions (Wright 2014). Labour supply questions in this region are complicated by the presence of aquaculture as well as capture fisheries. The aquaculture industry has been touted as providing good, year-round employment in rural communities (e.g. Bernal et al. 1999, Buck et al. 2004, DFO 2010, Perez-Sanchez and Muir 2003, Surprenant 2010, Walters 2007). According to the Department of Fisheries and Oceans (DFO),

Aquaculture presents employment opportunities and economic growth in remote, rural and coastal communities across Canada including in First Nations and other Aboriginal communities. The industry has been important for local economies along the west and east coasts where employment in wild fishery forestry and mining sectors has declined. In turn, the industry has benefitted from a stable and experienced workforce (DFO 2010)

Are the employment contributions of aquaculture and employer claims about out-migration to other provinces sufficient to explain the apparent labour shortages in the sector in this region that have been used to justify reliance on the TFWP? How crucial are other factors including employer-initiated changes in the quality of employment opportunities and definitions of appropriate workers to understanding the labour shortage?

\section{Methods}

This case study draws on findings from a review of relevant documents (newspaper articles between 2011-2016, news releases, government reports) and ethnographic fieldwork (between August and October of 2012) resulting in 36 interviews with seafood processing workers, plant managers, and key informants in NB and NL (See Table 1). To protect the workers who participated in the study, all community and company names are not identified, and participant names are pseudonyms. 
Table 1: Interview Participants

\begin{tabular}{|lccc|}
\hline & NB & NL & Total \\
\hline $\begin{array}{l}\text { No. Interviewed } \\
\text { Worked in Plants }\end{array}$ & 17 & 4 & 36 \\
$\begin{array}{l}\text { now/previously } \\
\text { Aquaculture Industry }\end{array}$ & 12 & 4 & 21 \\
$\begin{array}{l}\text { Wild Industry } \\
\text { Business Owners/ } \\
\text { manager/Key Informants }\end{array}$ & 14 & 0 & 12 \\
Plant Management/HR & 4 & 4 & 20 \\
\hline
\end{tabular}

*Some overlap exists between NB and NL as some interviewees worked in both locations. Overlap also exists in the number of workers working in aquaculture or wild seafood plants as some interviewees worked in both. 2 of the NB workers came to Canada through the TFWP.

*While 21 interviewees worked in the plants, 12 of them worked in the plants as their main source of income and were either currently working there or were retired. The remaining 9 had previously worked in seafood processing but were now working elsewhere.

\section{Historical Overview of NB Seafood Processing Labour Mobility}

This section briefly outlines the changing mobility and immobility of NB seafood processing workers in the region of my study over time, from inception in the late 1800 s to 2012 . The changes are tied to the cumulative effects of transnational corporate restructuring, national level labour migration policies, and local level resource boom and busts, occurring both in NB, as well as in other provinces (and states). These provide push and pull factors for interprovincial and international labour mobility into and out of the NB area, sometimes with the same workforce via circular migration patterns.

The NB seafood processing industry in the region of my case study has relied on migrant or mobile labour to transform its labour force since its inception in the late- $19^{\text {th }}$ century, recreating cheap and at times, indentured forms of labour. The historical cannery workforce was comprised of cheap, newly immigrated, mostly white European workers, whose descendants were still a significant portion of the workforce in 2012. The original workforce was enticed to the company by the promise of both stable work and housing. These workers grew up within a very isolated and immobile company town model, which included a paternal and controlling relationship between the workers and the company. The town 
was essentially owned and maintained by the company, and "citizens" were workers. The company model stayed fairly intact until the 1960 s and thus up until that time all workers were local, immobile, and wedded to the company through their community and family life.

In 1967 the company was sold to a large multinational conglomerate and began to divest itself of aging and costly assets, selling most businesses, houses, and cars. At this time the company began opening its doors to new workers. With the demise of the company town model, and thus the control over the workforce, a new reserve army of labour began to form. During the 1970s Vietnamese and Acadian workers from the surrounding areas entered the plants. The Acadian workforce did not remain long, and their departure was instigated by the one and only attempt to unionize the plant, which resulted in a mass layoff of all involved in organizing (see McFarland 1980). Vietnamese workers, whom had immigrated to a nearby urban center about an hour away, were unable to find work and began working in the seafood processing plants. Initially commuting to work, they eventually moved and integrated into the community.

Seafood processing during the 1980s witnessed little change to the labour force, but at this time the contraction in the wild fishery, especially the herring fishery, and the expansion in the aquaculture industry occurred. Many locals, including former herring weir fishermen, started small aquaculture businesses including processing, and hired workers from the local area (Marshall 2001). The largest wild seafood processing company consolidated during this time, closing many of its smaller processing plants.

Significant changes in seafood processing employment occurred again between the late 1990s and early 2000s. The collapse of the cod fishery in NL resulted in an abundance of seafood processing workers looking for work, yet wanting to maintain ties to home. The booming (yet contracting) aquaculture industry, and the somewhat stable herring industry offered seasonal employment for 5-6 months of the year. Actively recruited by processing companies, NL workers began moving to NB seasonally to work, engaging in circular migration to NB and back. Since about 2009 the number of NL workers has been decreasing in NB seafood processing plants. In 2012, one manager estimated about a 50 percent decrease in NL workers in the plant.

Managers offered varying explanations for the decrease. For aquaculture companies, the decline in NL workforce was explained as being tied to the change of harvesting and processing in this industry from seasonal to year-round production. Year round production negated the need for a seasonal reserve army of labour during peak production periods. Many workers from NL either had to find work in other plants, choose to stay permanently, or not come at all. 
Intense consolidation of the aquaculture industry at this time was due in part to infection salmon anemia (ISA) and sea lice outbreaks, which bankrupted many small companies through the 1990s and early 2000s (Harvey and Milewski 2007). As the remaining major aquaculture company expanded, it restructured work in these plants, lowering wages, and switching to year-round production (despite maintaining seasonal peaks and lows).

Mary: When they first took over a long time ago, they laid a lot of people off. Laid a lot of people off and then wanted to hire them back for five dollars an hour less. And a lot of the workers said FU and they were out of here. And at the time, managers or whatever said, white people don't want to work here, fine, we won't hire them. And after that a lot of the foreigners were brought in, because they could not get people to work here. Because they bought all these companies out. Laid everyone off, they did, they made no bones about it. They laid everyone off and lowered wages.

The initial reduction of wages has been maintained by the company, which pays the lowest wages out of the four processing plants currently operating in the area, despite its significant growth and prosperity.

For the processing plants that processed wild seafood and still maintained a seasonal peak production period, a variety of reasons were provided to explain the loss of NL workers. Managers credited the cause of the reduction in NL workers to both increases in local NL employment opportunities and attrition, due to the aging workforce. Employees in the plants explained the reduction in workers, and especially NL workers, differently, stating the latest ownership has coincided with deteriorating work environments, including descriptions of alienation, reduced hours, shifts, and overtime, as the main cause.

Renée: They are not nice people. You are just a number to them now. One time, if you didn't have your hours, they'd bend over backwards to get your hours. These people? You're just a number. I was talking to people from NL yesterday, and they said they don't think they are coming back, next year. They think they're done.

Jane (from $N L$ ): You know what? I can tell you why. I am going to be quite honest. The first, say the first four years for sure we were going there, like, we felt appreciated. Right, they, I mean it was a good atmosphere, the workers like you looked forward to going to work. But the new company took it over a few years ago...I have worked in fish processing for thirty-five years, and I have never ever seen a company treat the employees the way this company treats them. 
In addition to detrimental work environments, a significant factor in the reduction of the NL workforce was a forced pay cut for all workers, and for the seasonal NL workers, a loss of their seniority. The loss in seniority makes it more difficult to access shifts and pay raises that came with accumulating hours. Workers residing in the community year round (including TFWs) would be able to gain more hours than workers from NL. The forced pay cut came in 2011, when changes to workers collective agreement were accepted under the threat of plant closure. The company rationalized the decrease in wages due to a combination of low herring catches and competition with other herring companies that paid significantly cheaper wages (Stechyson 2011). For the NL workers, the ability to return home is the very reason they seek work in NB. Thus having the employer propose a loss of seniority unless they move permanently to the community or quit, does two things. It reduces the number of NL workers making the commute and, as a result, creates a local labour shortage that allows them to claim they need to tap into the overseas labour market, via the TFWP. This shows the calculated decisions on the part of upper management to significantly decrease a workforce in a short amount of time. For workers coming from NL that decide to remain working with the company, the loss of their seniority means that they are maintained at a cheaper wage for a much longer time, and are not in position to secure hours or shifts due to their low seniority.

The international mobility of workers in this area via the TFWP began in the mid- to late-2000s. Since 2010, companies processing seafood in NB have brought in more migrant workers through the TFWP than all other occupations in NB, at 48 percent of the total in 2012 (See Table 2).

The overall trend in seafood processing occupations since 2008 has been an increase in migrant workers brought in through the TFWP. In the area of my research in NB approximately 400 TFWs had been brought in to work by 2012 . The fish processing industry had brought in approximately 350 of those workers (although the exact numbers have not been documented) to work in three seafood processing plants employing approximately 1200 in total. 
Table 2: TFW in NB and in NB Seafood Processing Industry 2008-2012

\begin{tabular}{|lccl|}
\hline \multicolumn{2}{|l|}{$\begin{array}{l}\text { Total Number of TFW Labourers in Seafood } \\
\text { Processing in New Brunswick 2008-2012 }\end{array}$} & $\begin{array}{l}\text { Total Number of TFW in New } \\
\text { Brunswick 2008-2012 }\end{array}$ \\
\hline Year & \# of TFW & \% of NB TFW & \# of TFW \\
2008 & 165 & 9 & 1775 \\
2009 & 200 & 13 & 1520 \\
2010 & 637 & 36 & 1780 \\
2011 & 1075 & 43 & 2495 \\
2012 & 1120 & 48 & 2345 \\
\hline
\end{tabular}

(HRDC 2014)

The largest plant, with a workforce about 800, employed the least amount of workers through this program, thus a significant portion of the other two plants' workforces were comprised of workers through the TFWP. Migrant Workers coming to work in the seafood processing plants through the TFWP in this area of NB have usually been coming for one year, and then have it extended. Many apply for residency through the provincial Nominee Program. ${ }^{1}$

In 2012, workers brought in through the TFWP in NB made up 0.74 percent of the provincial labour force, more than 5 times the amount it was in 2002, and had the second largest growth rate in Canada (Lemieux and Nadeau 2015). NB also had one of the highest unemployment rates of the Canadian provinces in 2011, at 9.5\%, which had been increasing during the previous five years (New Brunswick 2013). Thus the labour shortage in this region and industry in NB seems counter-intuitive.

\section{The TFWP and Labour Shortages}

Labour shortages have been a driving force for the significant increase in the use of LSPP in the last decade (Marsden 2011). Part of the labour

1. Normally TFWs are allowed to stay for four years (this was extended from one year limit to two in 2007, and then from two to four in 2011, then reduced back to 2 in 2014), and then must not return to Canada for four years. Some provinces, including NB, have agreements with the federal government that allow workers to apply for permanent residency through their employer. While the program in NB is called the Skilled Worker Applicant With Employer Support, workers who work in some low skill occupations are eligible. These include occupations in NOC skill level C and D that fall under the skill types $1,3,7,8$, and 9 . Thus workers in seafood processing plants are eligible. 
shortages in my case study were created through qualitative aspects, or the combination of negative changes within the industry, including the work environment, pay, and the loss of the association of seafood processing work as a "good job" within the community. The TFWP has been shown to decrease the rate of interprovincial migration in some areas, and increase it in others (Gross and Schmitt 2012). Decreased internal mobility is demonstrated by the displacement of youth and inter-provincial migrants, such as replacement of the NL workers coming to NB by workers brought in through the TFWP. This final section uses the case study to explore qualitative aspects of the labour shortage in seafood processing in NB.

Aspects of Qualitative Labour Shortages in the NB Seafood Processing Industry

There have always been qualitative and quantitative elements to labour shortages. Sharma (2006) argues that labour shortages are qualitative, not just quantitative, because shortages of a particular type of worker can occur. She argues that a temporary migrant class of worker allows companies to restructure their labour force, accessing a cheaper (and more compliant) labour pool, arguing, "[w]hat there is a shortage of is a particular kind of workforce that can be filled by unfree, contract labour. In other words, in Canada, there are shortages of cheapened and politically subjugated labour power" (2006: 109). This paper builds on Sharma's (2006) insight with a specific example of how qualitative labour shortages are created.

Qualitative elements of labour shortages in NB have included which workers have been defined as "good workers". In NB this has changed over time, from local workers, to intra, then inter-provincial workers, and now defines workers using the TFWP. For example, when asked the composition of their workforces, managers of the three seafood processing plants using the TFWP stated that they brought workers in from overseas because they could not find enough local workers. The issue with applicants in fish processing was not necessarily that workers were not applying for jobs in the plants, but more so that managers were having difficulty finding the "right workers." Belinda recounts: "Uh, first when I came, it [labour turnover] seemed to be quite high. Again we've worked really hard to retain people, keep the right people."

In contrast, workers from overseas became the "right people" or the "good workers". For example: 
Carrie: What we have learned from other employers in the community is that employees from foreign countries, they are eager for any work whether it is repetitive type of work, factory setting, it doesn't matter to them. They want the work, they want as many hours as they can.

Kim: For some reason, they are not hiring local people. Well I know why, but...

Interviewer: Well, why do you think?

Kim: Cause they work hard, they don't complain, they work as many hours as they want them to, and they are not going to say nothing, and they are just content getting paid.

What seems to be missing from the characterization of these workers as hard workers is their position as "captive" labourers, tied to one employer, removed from family and friends, possibly trying to gain residency status. Thus, the changing definition of what makes a "good" worker contributes to labour force change in the plants that is not directly tied to a quantitative shortage of workers.

The qualitative nature of the labour shortage was made more apparent through my discussion with the manager at the second, smaller aquaculture plant in the region. This aquaculture processing plant does not have labour recruitment or retention issues, despite its location in the same community, and recruiting from the same labour pool as those using the TFWP. It hires local workers and pays significantly higher wages than the other aquaculture plant, offering both full benefits, and a better working environment.

Interviewer: How do you hire workers here?

Jacob: Um, basically to be honest, people like working here, so it hasn't been a real difficult thing to do, so mostly we've got a stock of applications and when a position is up, we go through those applications and we'll hire the best qualified, you know the one we think is the best person to do the job[...]

Interviewer: Ok, do you have problems with retention at all with workers?

Jacob: No, nope, and uh that is because people by and large like stability, and they know that there are going to get, you know their basic 40 hours a week, 52 weeks a year.

Therefore labour shortages in this region of NB, in the seafood processing industry experience both qualitative and quantitative labour shortages, but the use of the TFWP seems to have been greatly aided by quali- 
tative aspects of the labour shortage. The increasing use of the TFWP is contributing to changes in the work environment and rhythm of the workplace for all workers. Work rhythm changes are due to the level of control employers have over the workers coming in through the TFWP, and in response, the level of work effort put in by these migrant workers, which then sets a new bar for what is considered a "good worker".

\section{Cheap Labour based on Race, Class and Gender Recreated via the TFWP}

With the advent of the federal TFWP, firms in low skill areas were able to gain access to not only cheaper labour, but also labour they could control. Peck (1992: 342) states "[t]he labor process and labor market are much more than cost structures; they are arenas of political power and conflicting class, gender, and ethnic forces. Firms' labor adjustment strategies are not calculated on the back of the proverbial envelope; they are formulated within the confines of ongoing imperatives of labor control". With high labour control, exploitation can more easily occur. With high labour control, exploitation can more easily occur. For example, Viviane is a migrant worker in NB who works at both a seafood processing plant and a net mending plant - which are owned by the same company. Extra hours can be accrued from one workforce by taking workers from the net mending plant, and moving them over to the seafood processing plant. Extra hours can be accrued by taking workers from the net mending plant, and moving them over to the seafood processing plant. Viviane explains why she works both jobs:

Viviane: We need, mostly the Filipino's need more work, so our company has extra work to give us, so sometimes we work in the [name] fish plant and sometimes we work in [other fish plant name]. If what the plant needs, in fish plant we work, but mostly we work at the [name of plant] at the night, because their schedule is the nighttime. So all of the Filipinos are ready, because we need money to send to our families, so we must have an extra hours nap because our plant we just work eighty hours for two weeks, last time, almost a year we can get more hours because they want us to work. But when the government says just eighty hours per two weeks. So, that is why our, what you call it, our department said that we must have to work just until eighty hours, so you don't. If you work for more hours, so not in our shop, but you could work in the fish plant.

This process of using one workforce in two workplaces not only allows workers coming in through the TFWP to work more hours than if they were only working in one workplace, it also saves companies money, as they have ready access to a reserve labour pool for two workplaces. 
Companies can pay costs to import a reserve labour pool that is able to shift horizontally to different subsidiaries of the larger company, as need arises. This not only feeds on the vulnerability of the migrant workers, but also creates vulnerability in the domestic workforce.

It is the underlying gendered, classed, and racialized aspect of the TFWP that makes these workers more vulnerable to exploitation (Preibisch and Binford 2007, Preibisch 2010; Hennebry 2010). This vulnerability is based on the "othering" that occurs when segmentation of a workforce (or society) is done via social constructions of difference, which equate to inequalities in power. In this case, "othering" occurs through different rights and power within the workplace due to the structure of the TFWP. Preibisch and Binford (2007), and Preibisch (2010) outline how employers target specific countries based on racialized and gendered stereotypes. Priebisch (2010) identified employers using stereotypes that target specific individuals from specific countries to work in Agriculture in Canada. These employers associate individual abilities, personality and learning capabilities with ethnicities (Lendaro and Imdorf 2012) in order to identify who they want to employ in what jobs. I found managers in NB making these associations. For example:

Carrie: So far the information we have gathered, the piece-work jobs, you know you have to be very good with your hand-eye coordination, and dexterity is absolutely essential, you're getting paid based on what you pack so you have to be able to pack the fish as quickly as you can, as safely as you can, so you know, being, having someone who has a lot of dexterity in their hands is certainly valuable, so in some respects the Asian community can be an asset on that, cause their often, you know they have daintier hands, they are familiar with that kind of work, that is something that is very, very, common in their countries, so if we were looking for piece work I think we would probably look at, or I would probably suggest maybe looking in the Philippines for that. If we were looking for other positions throughout the plant, not to say we wouldn't put someone from Asia in a different position other than piecework but um, then we might we might look at maybe Romania for another example.

This racial and ethnically based stereotyping that infuses hiring practices for temporary foreign workers exemplifies how the increase in the use of the TFWP is a trend towards a labour force that is marginalized, underpaid, and without any ownership claims or political voice. It is recreating racialized stereotypes in this industry in NB (which has been shown to cluster occupational health and safety risks via ethnicities and nationalities - see Premji et al. 2014). It is also building on the already gendered division of labour that has existed with the history of the Canadian seafood processing industry. 


\section{CONCLUSION}

This article examines the contentious nature of the use of the TFWP in Canada, especially in areas of high unemployment, through a case study of the seafood processing industry labour shortage in one region in NB. Investigating employment related mobility and contentious labour mobility within the context of both quantitative and qualitative labour shortages, this study reveals how a historical immigrant seafood processing workforce became local and immobile, and then were gradually replaced with increasingly more mobile workers starting intra-provincially, then inter-provincially, to international workers through the TFWP. By linking critical immigration research with existing mobility research and adding to both literatures a deeper understanding of the interrelationship between multiple types of E-RGM in one industry, this paper shows how labour shortages have inherent class, race and gender inequalities which are being recreated through the use of the TFWP. The ramifications for the continued and increasing use of the TFWP in this industry and sector is an increasingly more precarious work environment for all workers. The current reorganization of labour within the seafood processing industry in NB is connected to a similar global trend. This trend towards cheaper labour is tied to regional, provincial, and global labour markets, and policy trends that are linking mobility across geographic scales. These include decreases in local, and inter-provincial labour in some areas, and increased inter-provincial work-related mobility in others. This is relevant for not just the seafood processing industry in NB, but also other seafood processing companies in Atlantic provinces, as well as other food processing and agricultural industries where the use of the TFWP due to labour shortages raises questions around worker (human) rights, employment and mobility.

\section{REFERENCES}

Aurora, The. 2014. Seafood industry labour is a Canada-wide problem, MacKinley. July 3, 2014.

APEC, Atlantic Provinces Economic Council. 2014. The Growing Role of Temporary Foreign Workers in Atlantic Canada Report Card May 21, 2014. https://www.apec-econ.ca/about-us/news/view/?do-load=1\&news. $\underline{\mathrm{id}=116 .}$.

Basok, Tanya. Human Rights and Citizenship: The case of Mexican Migrants in Canada. Working Paper no. 72. Centre for Comparative Immigration Studies. https: //escholarship.org/uc/item/3m1168t3 
Benach, Joan, Carles Muntaner, Haejoo Chung and Fernando G. Benavides. 2010. Immigration, employment relations, and health: Developing a research agenda. American Journal of Industrial Medicine 53: 338-343.

Bernal, Patricio. A., Oliva, Doris, Aliaga, Bernardo, and Morales, Carmen. 1999 'New regulations in Chilean fisheries and aquaculture: ITQ's and territorial use rights' Ocean and Coastal Management 42 (2-4) 119-142.

Brysk, Alison and Gershon Shafir. 2004. People Out of Place: Globalization and the Citizenship Gap. Routledge Press.

Buck B. H., Krause, G., and Rosenthal, H. 2004 'Extensive open ocean aquaculture development within wind farms in Germany: the prospect of offshore co-management and legal con-straints' Ocean and Coastal Management 47 (3-4): 95-122.

Büscher, Monika and John Urry. 2009. Mobile Methods and the Empirical. European Journal of Social Theory 12(1): 99-116.

Canada. 2014. Overhauling the temporary foreign workers program: Putting Canadians first. Government of Canada July 21, 2014. Accessed on July 22, 2014. http://www.esdc.gc.ca/eng/jobs/foreign_workers/reform/index.shtml.

CBC News. 2011. Mariner Seafoods must pay $\$ 150$ K to foreign workers. July 18, 2011. Accessed on October 14, 2014. http://chc.ca/news/canada/ prince-edward-island/mariner-seafoods-must-pay-150k-to-foreignworkers-1.1103238

CBC News. 2012. Easter concerned about EI changes. April 20, 2012. Accessed on February 13, 2013. http://www.cbc.ca/news/canada/new-brunswick/ story/2012/04/20/nb-easter-ei-changes.html

CBC News. 2014a. Temporary foreign workers have better work ethic, some employers believe. April 8, 2014. Accessed on May 1, 2014. http://www. cbc.ca/news/temporary-foreign-workers-have-better-work-ethic-someemployers-believe-1.2600864

CBC News. 2014b. A better work ethic? CBC readers weigh in on a debate over temporary foreign workers. Your Community Blog. Devon Goodsell. April 9, 2014. Accessed on April 26. http://www.cbc.ca/newsblogs/ yourcommunity/2014/04/a-better-work-et...cbc-readers-weigh-in-ondebate-over-temporary-foreign-workers.html

CBC News. 2014c. McDonald's foreign workers call it 'slavery'. The National. April 17, 2014.

CBC News. 2014d. 'I'm the cheapest worker': foreign worker denied overtime. May 15, 2014. Accessed on October 14, 2014. http://www.cbc.ca/news/ canada/saskatchewan/i-m-the-cheapest-worker-foreign-worker-deniedovertime-1.2641940 
CBC News 2014e. Lobster jobs at risk over temporary foreign workers changes: Not enough Canadians will do long hours and shift work, companies say. July 2, 2014. Accessed on July 16, 2014. www.cbc.ca/news/canada/newbrunswick/lobster-jobs-at-risk-over-temporary-foreign-workers-changes

CBC News. 2014f. Temporary foreign worker dies in freak accident, leaves chilling testimony. September 9, 2014. Accessed on September 12, 2014. http: cbc.ca/news/canada/montreal/temporary-foreign-worker-dies-infreak-accident-leaves-chilling-testimony-1.2760160

CBC News. 2016. Seafood Plants able to hire more temporary foreign workers this year. March 17, 2016. Accessed March 30, 2016. http://www.cbc. ca/news/canada/prince-edward-island/seafood-plants-hire-temporaryforeign-workers-1.3495348

Cragg, C. Andrew. 2011. Neoliberalising immigration in Canada: The pilot project for occupations requiring lower-levels of formal training and the expansion of Canada's temporary foreign worker program. Thesis. Frost Centre for Canadian Studies and Indigenous Studies. Trent University.

Cresswell, Tim. 2010. Towards a Politics of Mobility. Environment and Planning D: Society and Space 28(1): 17-31.

Department of Fisheries and Oceans (DFO) 2010. Socio-economic impact of Aquaculture in Canada. Gardner-Pinfold Consulting Economists Ltd. Fisheries and Aquaculture Management, Ottawa. http://www.dfo-mpo. gc.ca/aquaculture/ref/aqua-es2009-eng.pdf

Fudge, Judy. 2011. The precarious migrant status and precarious employment: The paradox of international rights for migrant workers. Metropolis British Columbia Centre of Excellence for Research on Immigration and Diversity Working Paper Series. October 2011. No. 11-15.

Fudge, Judy and Fiona MacPhail. 2011. Temporary migration and precarious employment in Canada: illustrations from the restaurant sector. Conference Presentation Regulating for Decent Work: Regulating for a fair recovery. Geneva 6-8, July 2011.

Gardiner Barber, Pauline. 2013. "Grateful" subjects: class and capital at the border in Philippine-Canada migration. Dialectical Anthropology 37(3/4): 383-400.

Gardner Pinfold. Economic Impact of the New Brunswick Ocean Sector 20032008. November 2010. Gardner Pinfold Consulting Economists Ltd. Nova Scotia, New Brunswick.

Gravel, Sylvie, Bilkis Vissandjee, Katherine Lippel, Jean-Marc Brodeur, Louis Patry and Francois Champagne. 2010. Ethics and the compensation of immigrant workers for work-related injuries and illness. Journal of Immigrant and Minority Health 12(5): 707-714.

Grosfoguel, Ramon, Oso, Laura and Anastasi Christou. 2014. 'Racism', intersectionality and migration studies: Framing some theoretical reflections. Identities: Global Studies in Culture and Power. http://dx.doi.org/10.108 $\underline{0 / 1070289 X .2014 .950974}$ 
Gross, Dominique, M. 2014. Temporary foreign workers in Canada: Are they really filling labour shortages? C.D. Howe Institute Commentary No. 407. April 2014. 1-28.

Gross, Dominique, M., and Nicole Schmitt. 2012. Temporary foreign workers and regional labour market disparities in Canada. Canadian Public Policy 38(2): 233-63.

Guppy, Neil. 1987. Labouring on shore: Transforming Uncommon property into Marketable Products, In P. Marchak (ed) Uncommon Property: The Fishing and Fish-Processing Industries in British Columbia. Toronto: Methuen Publications.

Haan, Michael, Walsh, Deatra and Barbara Neis. 2014. At the crossroads: Geography, gender and occupational sector in employment-related geographical mobility. Canadian Studies in Population. 41(3-4): 6-21.

Harvey, Janice and Inka Milewski. 2007. Salmon aquaculture in the Bay of Fundy: An unsustainable industry. Conservation Council of New Brunswick, Fredericton, NB.

Hannam, Kevin, Mimi Sheller, and John Urry. 2006. Mobilities, immobilities and moorings. Mobilities 1: 1-22.

Hennebry, Jenna. 2010. Not just a few bad apples: Vulnerability, health and temporary migration in Canada. International Migration Research Centre Publication: Canadian Issues/ Themes Canadiens Spring 2010: 73-77.

Lee, Helen. 1983. Corporate Strategy in the British Columbian Fish Processing Sector. Masters Thesis, Simon Fraser University.

Lendaro, Annalisa and Christian Imdorf. 2012. The use of ethnicity in recruiting domestic labour: A case study of French placement agencies in the care sector. Employee Relations 34(6): 613-627.

MacDonald, Martha. 2006. Lessons and Linkages: Building a framework for analyzing the relationship between gender, globalization and the fisheries. In Neis, Barbara, Marian Binkley, Siri Garrard, and Maria Cristina Maneschy, eds. Changing Tides: Gender, Fisheries and Globalization. Winnipeg: Fernwood Publishing 18- 28.

Marsden, Sarah. 2011. Assessing the regulation of temporary foreign workers in Canada. Osgoode Hall Law Journal 49 (1): 39-70.

Marshall, Joan. 2001. Landlords, leaseholders \& sweat equity: changing property regimes in aquaculture. Marine Policy 25: 335-352.

McFarland, Joan. 1980. Changing modes of social control in a New Brunswick fish packing town. Studies in Political Economy 4 (Autumn): 99-113.

Mertins-Kirkwood, Hadrian. 2014. Labour mobility in Canada: Issues and policy recommendations. Canadian Labour Congress, October 2014. 
Morgan, Gwyn. 2014. Temporary foreign workers perform critical jobs. Globe and Mail. August 17, 2014. Accessed on August 21, 2014. http://www. theglobeandmail.com/report-on-business/temporary-foreign-workersperform-critical-jobs/article20088968/

Muszynski, Alicia. 1996. Cheap Wage Labour: Race and Gender in the Fisheries of British Columbia. Montreal: McGill-Queens University Press.

New Brunswick. 2007. A profile of fisheries and seafood industry in New Brunswick: Supplement to the report of the stakeholders action groups. September 30, 2007. New Brunswick Canada.

New Brunswick 2013. Post-Secondary Education, Training and Labour, Occupational Profiles. Accessed on May 16, 2014. http://www1.gnb.ca/0105/ op-pp/Default.aspx

Peck, Jamie. 1992. Labor and agglomeration: Control and flexibility in local labor markets. Economic Geography 68(4): 325-347.

Perez-Sanchez, E., and Muir, J. F. 2003 'Fishermen perception on resources management and aquaculture development in the Mecoacan estuary, Tabasco, Mexico' Ocean and Coastal Management 46 (4-5) 681-700.

Preibisch, Kerry, L. 2007. Local produce, foreign labor: Labor mobility programs and global trade competitiveness in Canada. Rural Sociology 73(3): 418-449.

Preibisch, Kerry and Leigh Binford. 2007. Interrogating racialized global labour supply: An exploration of the racial/national replacement of foreign agricultural workers in Canada. The Canadian Review of Sociology 44(1): $5-36$.

Preibisch, Kerry. 2010. Pick-your-own labor: Migrant workers and flexibility in Canadian agriculture. International Migration Review 44(2): 404-441.

Preibisch, Kerry. 2011. Migrant workers and changing work-place regimes in contemporary agriculture production in Canada. Int. Jrnl. of Soc. of Agr. \& Food 19(1): 62-82.

Premji, S. Shakya, Y. Spasevski, M. Merolli, J. Athar, S. Immigrant Women and Precarious Employment Core Research Group. 2014 Precarious Work Experiences of Racialized Immigrant Women in Toronto: A CommunityBased Study. Just Labour, 22 [online] http://www.justlabour.yorku.ca/ volume $22 /$ pdfs $/ 08$ premji_et_al_press.pdf

Roseman, Sharon, R. Pauline Gardiner Barber and Barbara Neis. 2015. Towards a Feminist Political Economy Framework for Analyzing EmploymentRelated Geographical Mobility. Studies in Political Economy. 95.

Sharma, Nandita. 2006. Home economics: Nationalism and the making of 'Migrant Workers' in Canada. Toronto: University of Toronto Press.

Sheller, Mimi and John Urry. 2006. The New Mobilities Paradigm. Environment and Planning A 38(2): 207-226. 
Silvey, Rachel. 2005. Borders, embodiment, and mobility: Feminist migration studies in geography. In Lise Nelson and Joni Seager (eds) A Companion to feminist geography. Blackwell Publishing Ltd.

Stainsby, Jill. 1994. "It's The Smell of Money": Women shoreworkers of British Columbia. BC Studies 103: 59-81.

Stechyson, Natalie. 2012. Workers at Connors Bros. Fish plant vote in favour of pay cut. Telegraph Journal, Business, Thursday, April 21, 2011, B1.

Surprenant, David. 2010. Aquaculture in Eastern Canada. Library of Canada Background Paper. February 2, 2010. 1-9.

Walters Bradley B. 2007. Competing use of marine space in a modernizing fishery: Salmon farming meets lobster fishing on the Bay of Fundy. Canadian Geographer 51 (2) (Summer 2007): 139-59.

Wiber, Melanie G., Young, Sheena and Lisette Wilson. 2012. Impact of aquaculture on commercial fisheries: Fishermen's local ecological knowledge. Human Ecology. 40: 29-40.

Wright, Teresa. 2014. Temporary foreign worker changes will have series affects on P.E.I. The Guardian June 21, 2014.

\section{ACKNOWLedgements}

I would like to thank the editors of this special edition, the reviewers of the paper, members of the Pub Club at MUN, Liam Swiss, Barbara Neis and Kelly Blidook for their invaluable feedback.

Christine Knott is a doctoral student in Sociology at Memorial University. Her current research focus includes an intersectional political ecological approach to investigations of rural fishing communities and employment changes in the industry, including the need for temporary foreign workers.

E-mail: christine.knott@mun.ca 
398 C Canadian Journal of Sociology/Cahiers Canadiens de Sociologie 41(3) 2016 